\title{
Problemy terminologiczne i deskrypcyjne dotyczące językowych aspektów ludzkiej kognicji
}

Terminological and descriptive problems concerning language aspects of human cognition

\author{
Jolanta MAZURKIEWICZ-SOKOLOWSKA \\ Uniwersytet Szczeciński/ University of Szczecin \\ E-mail: jolanta.mazurkiewicz@usz.edu.pl,
}

\begin{abstract}
The paper, presenting research within the scope of cognitive linguistics, concerns the problem of conceptualization of meanings by language users and terminological difficulties with the selection of terms for describing language aspects of human cognition. The aim is to present the referential fields of terms, such as schemas/frames, idealized cognitive models, mental spaces, as well as the cognitive mechanisms which hinder clear distinctions between them. The main goal of the author is an attempt to prove the thesis that the psychology reality principle to the largest extent satisfies the description of mental representation and processing of meanings in the categories of cognitive domains, mental spaces and conceptualizations.
\end{abstract}

Keywords: metalanguage, frames, ICMs, cognitive domain, mental spaces, processing of meanings

\section{Wstęp}

Rozwijająca się od lat 70. ubiegłego wieku lingwistyka kognitywna (zob. G. Lakoff/ M. Johnson 1980, G. Lakoff 1987, R. Langacker 1987, 1991, L. Talmy 1988) stawia sobie za cel charakterystykę języka w kontekście całokształtu ludzkiego poznania. Podobnie jak w ujęciach formalnych (zob. N. Chomsky 1957, 1964, 1981, 1995), obiektem badawczym jest kognicja, jej postać i mechanizmy funkcjonowania, odnoszące się do języka, jednak punktem wyjścia do badań są wypowiedzi użytkowników języka, uczestniczących w konkretnych zdarzeniach mownych, a nie - postrzegana jako autonomiczna - składnia i hipotezy dotyczące reguł gramatyki uniwersalnej.

Krótka, jak dotąd, historia badań kognitywno-lingwistycznych ${ }^{1}$ ukazuje wielość sposobów postrzegania kognicji, od klasycznego modelu kognicji, porównywanej do komputera (zob. N. Chomsky 1957, A. Newell/ H. Simon 1972, M. Minsky 1975), przez ujęcia koneksjonistyczne (zob. M. Gazzaniga 1985, D. Dennett 1987, J. Elman/ E. Thompson/ E. Rosch 1999) po koncepcje kognicji ucieleśnionej (zob. S. Gallagher 1986, F. Varela i in. 1991, A. Damasio 1994, 1999), jak i terminów, które służyć mają jej opisowi. Dotyczy to między innymi pojęć, przy pomocy których charakteryzowana jest mentalna postać wiedzy i języka, jak ramy pojęciowe (schemas, frames), idealne

${ }^{1} \mathrm{Tu}$ : w szerokim rozumieniu, obejmującym ujęcia formalne i te, ukierunkowane poznawczo na całokształt kontekstowy, zawarty w zdarzeniach mownych. 
modele kognitywne (idealized cognitive models (ICMs), domeny kognitywne (cognitive domains), przestrzenie mentalne (mental spaces). Terminy te, jak zauważa J. Taylor (2003), bywają używane synonimicznie na określenie tych samych konstruktów, ale też przy pomocy tych samych pojęć bywają określane różne konstrukty (zob. J. Taylor 2003: 89).

Niniejszy artykuł ma na celu przybliżenie obszarów odniesienia tych pojęć, naświetlenie mechanizmów kognitywnych, które utrudniają jasne rozgraniczenia między nimi oraz próbę dowiedzenia tezy, że warunek realności psychologicznej, w najwyższym stopniu, spełnia opis mentalnej postaci znaczeń w kategoriach domen kognitywnych, przestrzeni mentalnych i konceptualizacji.

\section{Ramy pojęciowe i idealne modele kognitywne}

Ramy pojęciowe w ujęciu M. Minsky'ego (1975) stanowią mentalną reprezentację typowych sytuacji, wyabstrahowanych z indywidualnych doświadczeń, jak np. 'dziecięca impreza urodzinowa'. Są one definiowane jako ogólne formaty reprezentacji wiedzy, schematy, na które składają się wartości standardowe i miejsca puste, które wypełniają elementy zmienne (zob. M. Minsky 1975).

W ujęciu Ch. Fillmore'a, ramy to, pierwotnie, reprezentacje samej wiedzy językowej, obejmującej czasownik i cechujące go pod względem semantycznym przypadki, niezależnie od tego, ile $\mathrm{z}$ nich jest $\mathrm{w}$ danym zdaniu wyrażonych eksplicytnie. Jako łącznik między opisem sytuacji i jej reprezentacją syntaktyczną, rama przypadka nie musi zawsze zawierać opisu wszystkich jej aspektów, lecz może ograniczać się do określonych elementów składowych konkretnej sytuacji, w zależności od wybranego czasownika i perspektywy, którą on wyraża. Jako przykład, Ch. Fillmore przytacza sytuację transakcji handlowej, w której perspektywę zakupu towaru oddają czasowniki kupować (towar) i wydawać (pieniądze na towar), perspektywę sprzedaży towaru - czasownik sprzedawać, zaś perspektywę towaru - czasownik kosztować (zob. Ch. Fillmore 1977: 61-64, 72-73). W związku z tym, że rozumienie wypowiedzi łączy się z aktywacją szerszego kontekstu, Ch. Fillmore poszerza definicję ramy tak, że obejmuje ona wiedzę ogólną, istotną dla rozumienia (sceny, wyobrażenia, doświadczenia użytkowników języka, funkcje wypowiedzi) i podkreśla, że opis znaczenia i rozumienie wypowiedzi wymaga równoczesnej identyfikacji figury i tła, jak w przypadku oznajmienia wyjazdu 'nad morze', które automatycznie aktywuje w tle struktury konceptualne, jak 'na wieś' (zob. Ch. Fillmore 1977: 74). Fillmore wprowadza rozróżnienie między ramą przywoływaną (evoke frame) i interpretacyjną (invoke frame), z których pierwsza odnosi się do elementów standardowych, łączonych konwencjonalnie z danym wyrażeniem, a druga jest efektem interpretacji wyrażenia przez użytkownika języka pod wpływem inferencji kontekstowych, wiedzy i doświadczenia (zob. Ch. Fillmore 1985: 232, patrz też: A. Ziem 2008: 232-235).

Idealne modele kognitywne $\mathrm{z}$ kolei to termin wprowadzony przez G. Lakoffa (1987) jako narzędzie strukturyzacji przestrzeni mentalnych (G. Fauconnier 1985) (patrz: pkt. 2). Idealne modele kognitywne definiowane są jako złożone całości strukturalne, funkcjonujące w oparciu o określone reguły strukturyzacji. Reguły te wspóltworzą: i. struktura zawartości ram, skryptów i scenariuszy, wiązek cech, taksonomii, 
prototypów, ii. struktura schematów wyobrażeniowych oraz iii. projekcje metaforyczne i metonimiczne (zob. G. Lakoff 1987: 68, 284, patrz też: A. Ziem 2008: 26-28) ${ }^{2}$. Idealne modele kognitywne to zatem jednostki zintegrowane, bazujące na powtarzalnych doświadczeniach, uwzględniające współistnienie różnych reguł strukturyzacji wiedzy konceptualnej (zob. A. Ziem 2008: 26).

\section{Domeny kognitywne, przestrzenie mentalne, konceptualizacje}

W odróżnieniu od ram pojęciowych i idealnych modeli kognitywnych, opisujących uogólnioną, typową i wyidealizowaną zawartość znaczeń, statycznych i sztywnych, domeny kognitywne, przestrzenie mentalne i konceptualizacje cechuje dynamika, elastyczność i zmienność.

Domeny kognitywne, zgodnie z poglądem R. Langackera (1987), obejmują wszelkie treści pojęciowe i sfery doświadczenia mentalnego o różnym i zmiennym stopniu abstrakcji, które mogą stanowić bazę pojęciową znaczenia danego wyrażenia (zob. R. Langacker 2009: 71, 79) ${ }^{3}$. Tworzą one hierarchie/ taksonomie, w których znajdują się jednostki z wyższych i niższych poziomów organizacji pojęciowej. Podstawę znaczenia danego wyrażenia może stanowić każdy element, niezależnie od stopnia swojej złożoności, z każdego poziomu organizacji pojęciowej. Domeny, przywoływane przez dane wyrażenie, tworzą matrycę domen i są względem siebie w relacjach: mogą się przenikać, zachodzić na siebie, zawierać w sobie (zob. R. Langacker 2009: 71-76). Mogą być bardziej centralne lub peryferyjne, w zależności od tego, czy dane wyrażenie przywołuje je automatycznie: zawsze bądź często, czy tylko sporadycznie: w specyficznych kontekstach (zob. R. Langacker 2009: 76).

Ilustracji niech posłuży wyraz mlecz, który aktywuje domeny wyższych poziomów organizacji pojęciowej, jak [roślina], [kwiat], [ziele], [chwast] i niższych, jak [mniszek lekarski] czy [dmuchawiec]. Domeny [kwiat], [ziele], [chwast] mogą zachodzić na siebie lub się przenikać, zaś domeny [mniszek lekarski] i [dmuchawiec] mogą zawierać się $\mathrm{w}$ każdej z tych domen, choć bliższe tło dla domeny [mniszek lekarski] stanowi domena [ziele], a dla domeny [dmuchawiec] - domena [chwast]. O stopniu centralności/peryferyjności domen decyduje każdorazowo kontekst, którym może być np. czas (kwitnienia, przekwitania) - w odniesieniu do domen [kwiat] i [dmuchawiec], miejsce (łąka, trawnik w ogrodzie) - w odniesieniu do domen [kwiat] i [chwast], właściwości lecznicze - w odniesieniu do domeny [mniszek lekarski]. Domena [kwiat] jest szczególnie ciekawa: jako domena z wyższego poziomu organizacji pojęciowej, przywołuje generalnie wyobrażenie kwitnących roślin ozdobnych, w związku z czym, w odniesieniu do mlecza, stanowić będzie raczej domenę peryferyjną, podczas gdy, jako domena z niższego (względem $m l e c z a$ ) poziomu, na którym

\footnotetext{
${ }^{2}$ Odnośnie do skryptów i scenariuszy, patrz: R. Schank/ R. Abelson (1977), prototypów - E. Rosch (1975), schematów wyobrażeniowych - R. Langacker (1987), projekcji metaforycznych i metonimicznych - G. Lakoff/ M. Johnson (1980). Jak zauważa A. Ziem i G. Lakoff (1987) nie precyzuje pojęć: wiązki cech i taksonomie (zob. A. Ziem 2008: 26).

${ }^{3}$ Szczególnym rodzajem domen są tzw. domeny podstawowe, nieredukowalne poznawczo, jak [przestrzeń], [czas], [kolory], [dźwięki], [temperatura] (zob. R. Langacker 2009: 72).
} 
przywołuje 'kwiat', jako element budowy rośliny, jawić się może jako jedna z domen centralnych.

Jak podkreśla R. Langacker, każda ustalona matryca domen może zawsze zostać poszerzona o kolejne domeny, a treści znaczeniowe danego wyrażenia mogą być przypisywane różnym domenom matrycy (zob. R. Langacker 2009: 71).

Pojęcie przestrzeni mentalnych postrzegane jest jako synonimiczne dla domen kognitywnych. Tworzą je większe i mniejsze struktury konceptualne, pojawiające się nagle i spontanicznie w czasie trwania procesów przetwarzania informacji językowych. Odgrywają one swoistą rolę w strukturyzacji toczącego się dyskursu (zob. G. Fauconnier 1997: 11). Przestrzenie mentalne różnią się od domen pod względem operacji kognitywnych, w których biorą udział: aktywowane struktury przestrzeni mentalnych, fragmentaryczne, niespójne i zmienne, współuczestniczą w tworzeniu nowych jednostek konceptualnych. Domeny, jako bardziej stabilne i spójne, stanowią bazę pojęciową dla tych procesów (zob. R. Langacker 1987, 2009: 60, 80, A. Ziem 2008: 32).

Konceptualizacje z kolei definiowane są jako wszelkie przejawy doświadczenia mentalnego wszystkich modalności (motoryczne, sensoryczne, emocjonalne), wśród nich koncepcje, pojęcia, oceny, zarówno zakodowane w pamięci, jak i konstytuujące się w czasie trwania procesu przetwarzania (zob. R. Langacker 2009: 52-53).

Konceptualizacje mogą być statyczne, dynamiczne, utrwalone, nowopowstałe, proste, złożone. Mogą pojawiać się natychmiast lub rozwijać sekwencyjnie, jak w przypadku całych scenariuszy poznawczych, np. sekwencji czynności, wynikających z przepisu kulinarnego. Konceptualizację może stanowić także kontekst sytuacyjny i wcześniejszy dyskurs (zob. R. Langacker 2009: 72-73).

Procesy konceptualizacyjne zachodzą $w$ umysłach ludzkich nieustannie, w związku z czym konceptualizacje stanowią podstawowe sposoby interakcji ludzi ze światem (zob. R. Langacker 2009: 50-51, 61, 75-77). Dynamika konceptualizacji wynika z faktu, że są one procesem poznawczym i, jako takie, rozwijają się i ulegają modyfikacjom podczas procesu przetwarzania wyrażeń językowych przez użytkowników języka pod wpływem ich doświadczeń mentalnych (zob. R. Langacker 2009: 54-56). W powiązaniu z wyrażeniami językowymi, konceptualizacje są postrzegane jako znaczenia. Identyfikowanie znaczeń $\mathrm{z}$ konceptualizacjami, a nie $\mathrm{z}$ - postrzeganymi, jako bardziej statyczne - pojęciami, wiąże się właśnie z dynamiką tego procesu (zob. R. Langacker 2009: 18). Podkreślić należy, że zawsze aktywowany jest tylko pewien zakres znaczenia $\mathrm{z}$ całego spektrum znaczeniowego danego wyrażenia, w zależności od tego, ile i jakie treści dany użytkownik języka jest w stanie przetworzyć w danym momencie (zob. R. Langacker 2009: 85-128).

I właśnie $\mathrm{z}$ faktu indywidualnego i uwarunkowanego kontekstowo zróżnicowania operacji kognitywnych, biorących udział w procesach kategoryzacji, schematyzacji, konkretyzacji, wydobywania figury z tła, tak pod względem dynamiki, jak również stopnia ogólności/szczegółowości i kompleksowości, wynikają problemy terminologiczne, dotyczące nie tylko rozgraniczenia między domenami kognitywnymi, przestrzeniami mentalnymi i konceptualizacjami, ale i wymiennego i niejednoznacznego stosowania także i omówionych w pkt. 2 pojęć. 


\section{Problemy terminologiczne i deskrypcyjne}

\subsection{Domeny kognitywne, przestrzenie mentalne i konceptualizacje, jako narzędzia opisu procesu konceptualizacji znaczeń}

Na podstawie dotychczasowych rozważań można stwierdzić, że jedna i ta sam definicja, obejmująca zjawiska mentalnych doświadczeń, jak pojęcia (stałe, spontaniczne, nowe), doświadczenia sensoryczne, emocje, odczucia, dyskursy, bardziej lub mniej rozbudowane scenariusze i ich fragmenty, oceny kontekstów fizycznych, społecznych, kulturowych, językowych, ma zastosowanie zarówno do domen kognitywnych, przestrzeni mentalnych, jak i konceptualizacji. Zatem, czy dany koncept lub struktura konceptualna stanowi domenę, przestrzeń mentalną czy konceptualizację, zależy od etapu procesu konceptualizacji znaczenia danego wyrażenia i rodzaju operacji kognitywnych, w których one uczestniczą.

W przytoczonym powyżej przykładzie możliwych domen, przywoływanych przez wyraz mlecz, wszystkie one mogą stanowić także przestrzenie mentalne i konceptualizacje. W procesie konceptualizacji jego znaczenia może nastąpić odwołanie do wiedzy pojęciowej z domeny [rośliny] i jednocześnie, pod wpływem czynników kontekstowych i ogniskowanych elementów doświadczenia użytkownika języka, mogą otwierać się przestrzenie mentalne, dotyczące np. 'szkodliwego oddziaływania mlecza na inne rośliny', jego 'leczniczego oddziaływania na człowieka', 'intensywnie żółtych kwiatów’ czy też ‘kulistych skupisk białoszarego puchu przekwitłych kwiatów, zdmuchiwanych chętnie przez dzieci lub roznoszonych przez wiatr', skutkiem czego aktywowane zostanie, odpowiednio, znaczenie w postaci konceptualizacji chwastu, mniszka lekarskiego, kwiatu czy dmuchawca, a każde z nich otwierać będzie dalsze przestrzenie mentalne i przywoływać kolejne domeny. Powyższa konceptualizacja dmuchawca, która powstała $\mathrm{z}$ odwołania do domen kognitywnych [ludzie], [dzieci] (i konceptu: dzieci), [czynności] (i konceptu: zdmuchiwać), [emocje] (i konceptu: chętnie), [zjawiska atmosferyczne] (i konceptu: wiatr) powoduje otwieranie się dalszych przestrzeni mentalnych, np. 'biegających, roześmianych dzieci w letnich ubraniach', 'ciepłego, wiosennego wiatru', będących efektem odwołania do domen kognitywnych, jak [czynności] (i konceptów: biegać, śmiać się), [emocje] (i konceptu: radość), [pory roku], [czas] (i konceptów: wiosna, lato), [odzież] (i konceptu: letnie ubrania), [odczucia], [temperatura] (i konceptu: cieply). W procesie konceptualizacji pojawić się mogą także koncepty z domen [dorośli] (rodzicelopiekunowie/przechodnie), [zwierzęta] (psy, koty, owady), [kolory] (natury, ubrań), [materiał] (ubrań) itd.

Wymienione koncepty cechuje różny stopień ogólności/ szczegółowości, przy czym w powyższym opisie pozostają one na poziomie typu, natomiast w procesach przetwarzania wyrażenia przez indywidualnych użytkowników języka jawić się będą najczęściej jako konkretne obiekty (okazy). Wszystkie one mogą stanowić domeny w momencie, gdy następuje do nich odwołanie w procesie konceptualizacji, przestrzenie mentalne - w momencie ich pojawienia się w czasie trwania tego procesu, i konceptualizacje - proceduralnie - na każdym etapie, oraz, jako wynik procesu konceptualizacji, czyli znaczenie: struktura powstała w wyniku wydobycia i uwypuklenia 
określonych treści pod wpływem aktywowanych domen kognitywnych i przestrzeni mentalnych (zob. R. Langacker 2009).

\subsection{Konceptualizacje znaczeń pojęć, służących opisowi mentalnej postaci wiedzy $\mathrm{i}$ języka}

Odnośnie do możliwości zastosowań analizowanych w pkt. 1 i 2 niniejszego artykułu terminów, w literaturze przedmiotu można spotkać następujące stwierdzenia:

- ramy (schemas), jako bazy interpretacji i bazy danych (zob. M. Minsky 1975), są tożsame z ramami (frames) (zob. Ch. Fillmore 1977) (zob. A. Ziem 2008: 256-257);

- ramy (frames), domeny i przestrzenie mentalne są porównywalne, ramy (schemas) i modele kognitywne - nie w tym samym stopniu (zob. A. Ziem 2008: $34)$;

- domeny, ramy, modele kognitywne, sceny, schematy i skrypty są ekwiwalentne, (zob. R. Langacker 1987: 150);

- przestrzenie mentalne są strukturyzowane przez idealne modele kognitywne (zob. G. Lakoff 1987: 68);

- przestrzenie mentalne są strukturyzowane przez ramy (zob. G. Fauconnier/ M. Turner 1998: 137).

- pojęcie, koncepcja, konceptualizacja oraz domena (niepodstawowa), rama i idealny model kognitywny różnią się od siebie pod względem perspektywy: pierwsze trzy ogniskują treści znaczeniowe, drugie - umożliwiają pokazanie ich roli w konstytuującym się znaczeniu, przy czym najbardziej ogólne są terminy: konceptualizacja i domena. Konceptualizacja niweluje różnice między koncepcją i pojęciem, zaś termin domena, jako jedyny z pozostałych trzech, obejmuje swym zakresem także domeny podstawowe i elementy zdarzeń mownych w czasie ich trwania (zob. R. Langacker 2009: 74-75).

Przytoczone poglądy obrazują różnorodność konceptualizacji znaczeń pojęć, służących opisowi mentalnej postaci wiedzy i języka. Są one efektem indywidualnie zróżnicowanych procesów konceptualizacji, tak pod względem perspektywy oglądu, jak i elementów wydobywanych z tła pojęciowego na plan pierwszy, stopnia ogólności/uszczegółowienia i kompleksowości ogniskowanych treści i ich wzajemnych relacji. Czynniki te sprawiają, że w konceptualizacjach różnych badaczy określone terminy zdają się być tożsame lub odmienne.

Problem z wyborem terminów do opisu mentalnej postaci wiedzy i języka wynika więc $\mathrm{z}$ faktu, że kognicja to nie tylko reprezentacja, ale przede wszystkim proces. Jak wspomniano powyżej, procesy konceptualizacji toczą się nieprzerwanie, a przetwarzane wyrażenia aktywują kolejne obszary substratu pojęciowego i uruchamiają procesy, w wyniku których przywoływane są lub tworzone kolejne koncepcje i elementy treści znaczeniowych.

Wyróżnienie ram przywoływanych (wartości standardowych, które użytkownik języka wiąże z wyrażeniem ze względu na przynależność do wspólnoty językowej) i ram interpretacyjnych (będących wynikiem odniesień do informacji kontekstowych 
i inferencji) jest pewną próbą uwzględnienia procesowego aspektu kognicji: Wypełnianie miejsc pustych w ramach postrzegane jest jako praca konstrukcyjna użytkownika języka, wykonywana w oparciu o informacje, pochodzące z danych językowych, niewerbalnych źródeł, ogólnej wiedzy czy od partnerów rozmowy (zob. Ch. Fillmore, za: A. Ziem 2008: 284).

Jednak opisywanie procesu przetwarzania języka w terminach ram czy idealnych modeli kognitywnych, nawet z uwzględnieniem inferencji, interpretacji i konstruowania, nadal ogranicza je do zawartości struktur językowych, postrzeganych jako 'gestalty’, czyli całości, złożone z elementów, stanowiących ich integralne części. Wydobywa $\mathrm{z}$ tła treści standardowe, powszechne, racjonalne, typowe, idealne, a ich zmienność wiąże się jedynie z przyjętą perspektywą, bardziej lub mniej fragmentaryczną/bardziej lub mniej pełną konfiguracją elementów składowych sytuacji, modyfikacją uzusu. Nie uwzględnia zatem, a jeśli, to tylko marginalnie, treści znaczeniowych, przywoływanych przez użytkowników języka podczas przetwarzania wyrażeń językowych spontanicznie, indywidualnie i subiektywnie.

Trudno nie zgodzić się ze stwierdzeniem R. Langackera, że domeny stanowią termin najbardziej ogólny (zob. R. Langacker 2009: 74). Jako mentalne obszary wiedzy wszelkiej modalności, tworzące hierarchie od bardziej schematycznych po konkretne i wyspecyfikowane, obejmują ramy, schematy, idealne modele kognitywne, skrypty, scenariusze, konceptualizacje, a także przestrzenie mentalne. Koncepcje, stanowiące domeny danej matrycy domen, mogą tworzyć najróżniejsze konfiguracje (zob. R. Langacker 2009: 80). Jak wspomniano powyżej, za termin ogólny R. Langacker uznaje również konceptualizacje, które mogą być aktywowane jako element domen, przestrzeni mentalnych i efekt procesu konceptualizacji.

Z dotychczasowych rozważań wynika, że funkcjonowanie ludzkiej kognicji, w odniesieniu do reprezentacji i przetwarzania wiedzy i języka, najpełniej oddaje opis przy użyciu terminów domeny, przestrzenie mentalne i konceptualizacje. Odnoszą się one do mentalnych doświadczeń, zarówno tych zakodowanych w pamięci długotrwałej, jak i tych, powstających spontanicznie, ad hoc, w czasie procesu konceptualizacji treści znaczeniowych przetwarzanych wyrażeń i wypowiedzi. Pozwalają więc opisać nie tylko samą zawartość znaczenia, ale też uchwycić dynamikę procesu konceptualizacji, zarówno pod kątem pojawiających się treści znaczeniowych, jak i stopnia ich uszczegółowienia, elementów ogniskowanych i wydobywanych na plan pierwszy oraz perspektywy oglądu (odnośnie do obrazowania, patrz: R. Langacker 2009: 85128). Opis obejmuje więc aktywowane przez dane wyrażenie domeny, ich wzajemne relacje i stopień centralności/ peryferyjności w matrycy domen (tło pojęciowe wyrażenia), wydobywane $\mathrm{z}$ tła $\mathrm{w}$ procesie przetwarzania wyrażenia treści znaczeniowe, zarówno przywoływane z pamięci, jak i kreowane na bieżąco, oraz efekt procesu, czyli konceptualizację znaczenia, która sama w sobie jest także dynamicznie zmienna.

Zastosowanie terminów domeny, przestrzenie mentalne i konceptualizacje pozwala też na objęcie opisem tworów mentalnych, klasyfikowanych, jako prototypy, metafory konceptualne i blendy. Wszystkie one mogą występować w obszarze domen, przestrzeni mentalnych i konceptualizacji: zarówno i) prototypy, jako najlepsi przedstawiciele danej kategorii (wróbel dla kategorii 'ptak') (zob. E. Rosch 1975), ii) 
metafory konceptualne, jako efekt projekcji treści pojęć konkretnych na zjawiska abstrakcyjne (np. czas to pieniądz), metonimicznych projekcji części na całość (np. $m q$ dre głowy w odniesieniu do 'ludzi'), personifikujących projekcji ludzkiej aktywności na obiekty nieożywione (np. teoria zakłada) (zob. G. Lakoff/ M. Johnson 1980), jak i iii) blendy, jako efekt procesów integracji pojęciowej. W przypadku tych ostatnich, określone treści z przestrzeni wyjściowych przenikają się wzajemnie z aktywowanymi dalszymi treściami w przestrzeni generycznej i są integrowane do nowych pojęć w przestrzeni blendu (zob. G. Fauconnier/ M. Turner 1998, 2002, A. Libura 2007), jak w przypadku konceptu Zając, który, otwiera przestrzenie wyjściowe: 'zwierzęta' i 'Święta Wielkiej Nocy', aktywujące w przestrzeni generycznej treści, związane z symboliką świąteczną, integrowane w przestrzeni blendu do prezentu wielkanocnego, zwyczajowo słodyczy lub innego drobiazgu dla dzieci.

Znaczenie, jako tożsame z konceptualizacją, to rozumienie wyrażenia/wypowiedzi przez indywidualnego użytkownika języka w danym, konkretnym zdarzeniu mownym (zob. R. Langacker 2009: 51-53). Jest ono efektem wzajemnego oddziaływania treści znaczeniowych elementów składowych wyrażenia/wypowiedzi (na zasadzie niepełnej kompozycjonalności) i elementów dodatkowych (wiedzy encyklopedycznej, kontekstowej, doświadczenia), aktywowanych w procesie konceptualizacji znaczeń, poprzez wzajemne przenikanie, jako że nie istnieją ścisłe granice między znaczeniem językowym a wiedzą i doświadczeniem ogólnym i kontekstowym (zob. R. Langacker 2009: 79, 84).

Znaczenie nie jest ani w pełni otwarte, ani w pełni zamknięte. Jest ono zawsze wynikiem prawdopodobieństwa aktywowania określonych domen, które ma charakter losowy i jest wrażliwe na czynniki kontekstowe i zmienność uzusu (zob. R. Langacker 2009: 77-78). Znaczenie najczęściej więc wykracza poza schemat, ramę pojęciową czy idealny model i stanowi ich modyfikację, zależną od indywidualnie i subiektywnie aktywowanych treści różnych modalności.

Wobec powyższej argumentacji, warunek realności psychologicznej wyczerpuje najpełniej opis znaczeń $w$ terminach domen kognitywnych, przestrzeni mentalnych i konceptualizacji, jako że pozwala przedstawić zarówno treści znaczenia, jak i procesy konceptualizacji tych treści. Dowodzą tego już omówione powyżej przykłady. Warto jednak pokazać wartość poznawczą takiego opisu, stosując go do przykładu, znanego z literatury przedmiotu, jako kategorii standardowej, jak schemat, rama czy idealny model kognitywny. Za przykład posłuży więc, analizowane w literaturze przedmiotu w kategorii schematu (zob. M. Minsky 1975), wyrażenie 'dziecięca impreza urodzinowa'.

\subsection{Opis wyrażenia 'dziecięca impreza urodzinowa' $w$ terminach domen kognitywnych, przestrzeni mentalnych i konceptualizacji}

Poniższy diagram prezentuje aktywowane w toku przetwarzania wyrażenia 'dziecięca impreza urodzinowa' domeny kognitywne (w nawiasach kwadratowych), wybrane konceptualizacje (pisane kursywą), układy hierarchiczne/taksonomiczne (oznaczane strzałkami), koncepty, występujące w różnych konfiguracjach (pogrubione): 
- [ludzie] $\rightarrow$ [rodzina], [znajomi], [dzieci], [koleżanki i koledzy] $\rightarrow$ [emocje, odczucia, nastroje]

- [czynności] $\rightarrow$ [emocje, odczucia, nastroje]

-- przemieszczanie się (na imprezę, ale i w celu kupienia prezentu, stroju, wyjścia do fryzjera) $\rightarrow$ [sposoby]

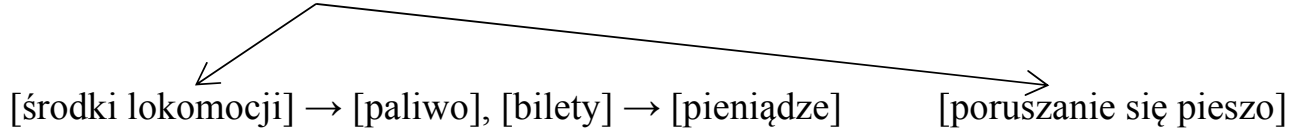

-- wybieranie, kupowanie, przygotowywanie

(prezentu, stroju) $\longleftrightarrow$ [przedmioty] $\rightarrow$ [ubrania], [kosmetyki], [zabawki], [art. spo-

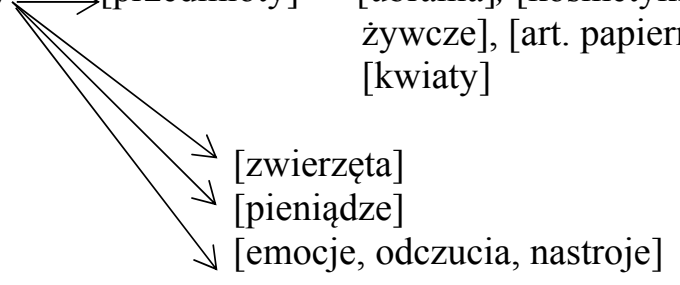

-- czesanie/wyjście do fryzjera $\rightarrow$ [emocje, odczucia, nastroje]

-- witanie, rozmawianie, żartowanie, jedzenie, picie, gry i zabawy, tańczenie, śpiewanie, żegnanie

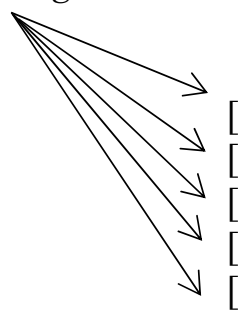

[relacje interpersonalne], [rozmowy, żarty], [tańce], [piosenki] [przedmioty] $\rightarrow$ [gry], [zabawki], [art. spożywcze], [kwiaty] [zwierzęta] [głosy, odgłosy], [hałas]

[emocje, odczucia, nastroje]

-- planowanie, organizowanie

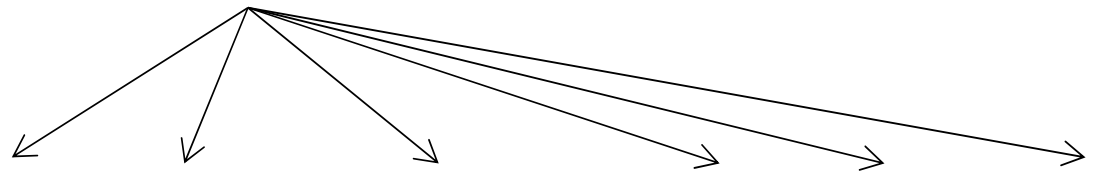

[obowiązki], [zadania], [przybory do pisania], [czas], [komórka], [lodówka] ${ }^{4}$

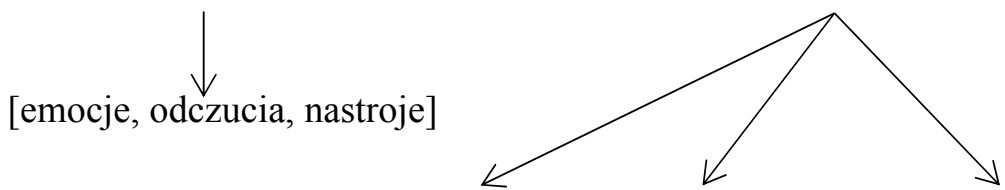

[czas na przygotowania, zakupy], [termin imprezy], [czas trwania imprezy] $\rightarrow$ [kalendarz] $\rightarrow$ [dni tygodnia] $\rightarrow$ [godziny] $\rightarrow$ [emocje, odczucia, nastroje]

${ }^{4}$ Do naklejania karteczek wspomagających pamięć. 
- [przedmioty]

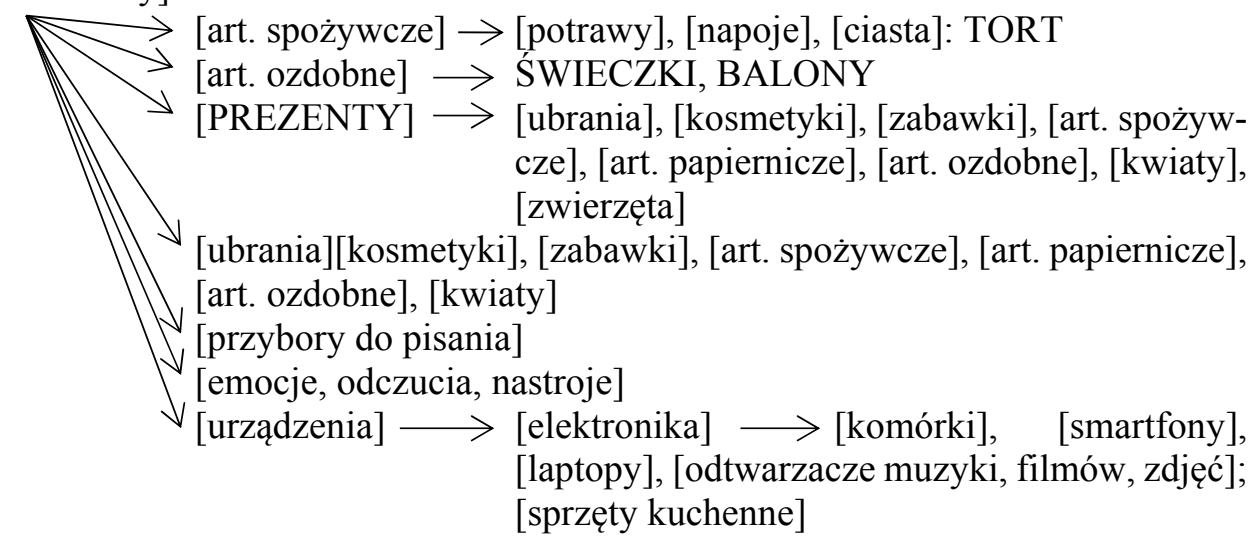

- [zwierzęta] (posiadane i obowiązki z nimi związane; prezent) $\rightarrow$ [emocje, odczucia, nastroje]

- [relacje interpersonalne] $\rightarrow$ [rozmowy, żarty], [tańce], [piosenki], [gry], [zabawy], [głosy, odgłosy], [hałas] $\rightarrow$ [emocje, odczucia, nastroje]

- [lokale] dom, ulubiony/modny/nowo otwarty lokal gastronomiczny $\rightarrow$ [wystrój], [klimat] $\rightarrow$ [emocje, odczucia, nastroje]

- [muzyka] $\rightarrow$ [emocje, odczucia, nastroje]

- [wspomnienia minionych imprez], [oczekiwania wobec imprezy], [wyobrażenia imprezy], [fragmenty sytuacyjno-dyskursywne, dotyczące wcześniejszych imprez/oczekiwanej imprezy] $\rightarrow$ [emocje, odczucia, nastroje] $\rightarrow$ [nastawienia]

Jak wynika z diagramu, przywoływane, jako prototypowe, treści znaczeniowe wyrażenia 'dziecięca impreza urodzinowa': TORT, ŚWIECZKI, BALONY, PREZENTY aktywują rozliczne domeny kognitywne o różnym stopniu ogólności/szczegółowości, jak [ciasta], [art. spożywcze] w przypadku TORTU, [art. ozdobne] w przypadku ŚWIECZEK i BALONÓW, [przedmioty], [rośliny], [zwierzęta] w przypadku PREZENTÓW. Wszystkie one, ale i wyrażenie, jako całość, aktywują domeny [ludzie], [czynności], [emocje, odczucia, nastroje] i otwierają przestrzenie mentalne, dotyczące wyobrażeń i oczekiwań wobec imprezy, jej organizacji i przygotowania, rozplanowania innych obowiązków, wspomnień minionych imprez, osób-uczestników imprezy, osób, pośrednio związanych z imprezą, jak fryzjerzy, taksówkarze, cukiernicy, kucharze, ekspedienci, ich wyglądu, charakteru, zachowania, w przypadku tych drugich - także efektów ich pracy. Każda z wymienionych koncepcji w procesie przetwarzania wyrażenia może być przywoływana, jako konceptualizacja w obrębie domeny/domena, w obrębie przestrzeni mentalnych i/lub jako konceptualizacja/ fragment konceptualizacji wykreowanego, w toku procesu, znaczenia. Każda z nich może stanowić element bliższego/dalszego tła pojęciowego konceptualizowanego znaczenia bądź być wysuwana na plan pierwszy, jako element wykreowanego znaczenia, przy czym miejsce i rola każdego z tych elementów, jak i stopień ogólności/szczegółowości każdego z nich, może się dynamicznie zmieniać w czasie trwania procesu 
przetwarzania wyrażenia.

Najwyższy poziom centralności cechuje domeny [ludzie], [czynności], [emocje, odczucia, nastroje], [przedmioty] i [czas]. Domeny te cechuje także wysoki poziom ogólności, najwyższy - domenę [przedmioty]. W jej skład wchodzą: również dość ogólna domena - [prezenty], w obszarze której aktywowane mogą być elementy domen, jak [ubrania], [kosmetyki], [zabawki], [art. spożywcze], [art. papiernicze], [art. ozdobne], [kwiaty], [elektronika], [komórki], [smartfony], [laptopy], [odtwarzacze muzyki, filmów, zdjęć], jak i nienależąca do domeny [przedmioty] - domena [zwierzęta]. Wszystkie wyodrębnione domeny mogą stanowić niezależne domeny. W procesie przetwarzania analizowanego wyrażenia aktywują się one nie tylko w kontekście [prezentów], ale i wyglądu uczestników imprezy - w przypadku domen [ubranie] i [kosmetyki], zabawek, znajdujących się w domu dziecka-jubilata - w przypadku domeny [zabawki], wystroju lokalu - w przypadku domen [art. ozdobne] i [kwiaty], sprzętów i urządzeń tamże - w przypadku domeny [elektronika] czy zwierząt gości i gospodarzy - w przypadku domeny [zwierzęta].

Wyszczególnienie domeny [przybory do pisania], jako odrębnej w domenie [przedmioty] i pozostawienie jako niewyspecyfikowanej składowej domeny [art. papiernicze] w domenie [prezenty] ujawnia mechanizmy kognitywne, biorace udział w procesach kategoryzacji, schematyzacji, uszczegóławiania, wydobywania figury z tła: Domena [przybory do pisania] została wyodrębniona w domenie [przedmioty] w związku z jej aktywacją w kontekście czasowego planowania i organizowania zadań i obowiązków (podobnie jak domeny/konceptualizacje o dużym stopniu uszczegółowienia: [komórka] i [lodówka] - wszystkie konceptualizowane w kontekście możliwości zapamiętania/zapisania zadań do wykonania). [Przybory do pisania] cechuje w tym kontekście wyższy poziom centralności niż w kontekście [prezentów], dlatego w tym ostatnim pozostały niewyspecyfikowane. Koncepty komórka i lodówka, choć bardziej uszczegółowione, niż przybory do pisania zostały wyspecyfikowane w ogólnych domenach [elektronika] i [sprzęty kuchenne], odpowiednio, gdyż stanowią jednostki o dużym stopniu prawdopodobieństwa aktywacji także poza kontekstem narzędzi, ułatwiających zapamiętanie informacji, np. w celu zaproszenia gości bądź uzyskania zaproszenia (komórka), przechowania tortu i innych produktów spożywczych (lodówka).

Przytoczone przykładowe fragmenty możliwych procesów konceptualizacji treści znaczeń analizowanego wyrażenia pokazują dynamikę procesu, mechanizmy zazębiania, nakładania się, przenikania domen, dynamicznej zmienności roli różnych konceptów, jako elementów domen, przestrzeni mentalnych i konceptualizacji.

\section{Zakończenie}

Analiza wyrażenia 'dziecięca impreza urodzinowa' w kategoriach domen kognitywnych, przestrzeni mentalnych i konceptualizacji odsłania nie tylko wielość możliwych konceptualizacji, ale też mechanizmy kognitywne, przy udziale których one powstają. Każdy, aktywowany na danym etapie procesu przetwarzania wyrażenia, koncept może otwierać dalsze przestrzenie mentalne, przywoływać elementy kolejnych do- 
men i współuczestniczyć w kreowaniu ostatecznej (na dany moment) postaci znaczenia tego wyrażenia, wydobywając na plan pierwszy określone treści z tła pojęciowego.

Podkreślić należy, że przedmiotowe wyrażenie wydobywać będzie na plan pierwszy różne treści w zależności od perspektywy osoby, czasu i usytuowania: inne u dziecka-jubilata, inne u dzieci-gości, osób dorosłych (gospodarzy/gości) i inne w okresie zapraszania i przygotowań, inne przed samą imprezą, w jej trakcie i po. Ujawniające się mechanizmy kognitywne, biorące udział w tworzeniu znaczeń wyrażeń, uzmysławiają wycinkowy, fragmentaryczny i dynamicznie zmienny ich charakter $\mathrm{w}$ indywidualnych konceptualizacjach znaczeń przez użytkowników języka w konkretnych zdarzeniach mownych.

Co istotne, opis znaczeń wyrażeń w kategoriach domen kognitywnych, przestrzeni mentalnych i konceptualizacji, obejmujący treści o różnym stopniu ogólności/ szczegółowości i kompleksowości, uwzględnia konceptualizacje wszystkich poziomów organizacji pojęciowej, zarówno konkretne, jak i schematyczne. Spełnia zatem w najwyższym stopniu warunek realności psychologicznej w odniesieniu do funkcjonowania ludzkiej kognicji w kontekście przetwarzania wiedzy i języka.

\section{Bibliografia}

Chomsky, N. (1957), Syntactic Structures. The Hague.

Chomsky, N. (1965), Aspects of the Theory of Syntax. Cambridge.

Chomsky, N. (1981), Lectures on Government and Binding. The Pisa Lectures. Dordrecht.

Chomsky, N. (1995), The Minimalist Program. Cambridge.

Damasio, A. (1994), Descartes' Error: Emotion, Reason and the Human Brain. New York.

Damasio, A. (1999), The Feeling of What Happens: Body and Emotion in the Making of Consciousness. New York.

Dennett, D. (1987), The Intentional Stance. Cambridge.

Elman, J./ E. Bates/ M. Johnson/ A. Karmiloff-Smith/ D. Parisi/ K. Plunkett (1999), Rethinking Innateness. A connectionist perspective on development. Cambridge.

Fauconnier, G. (1985), Mental spaces. Aspects of Meaning Construction in Natural Languages. Cambridge.

Fauconnier, G. (1997), Mappings in Thought and Language. Cambridge.

Fillmore, Ch. (1977), The case for case reopened, (w:) P. Cole/ J. Sadock (red.), „Syntax and Semantics". New York, 59-81.

Fillmore, Ch. (1985), Frames and the semantics of understanding, (w:) „Quaderni di Semantica" 6 (2), 222-254.

Gallagher, S. (1986), Body Image and Body Schema. A Conceptual Clarification, (w:) „Journal of Mind\&Behavior” 7 (4), 541-554.

Gazzaniga, M. (1985), The social brain: Discovering the networks of the mind. New York. 
Lakoff, G. (1987), Women, Fire, and Dangerous Things. What Categories Reveal about the Mind. Chicago.

Lakoff, G./ M. Johnson (1980), Metaphors We Live By. Chicago.

Langacker, R. (1987), Foundations of cognitive grammar. Vol. I. Theoretical Prerequisites. Stanford.

Langacker, R. (1991), Foundations of cognitive grammar. Vol. II. Descriptive Application. Stanford.

Langacker, R. (2009), Gramatyka kognitywna. Kraków.

Minsky, M. (1975), A Framework for Representing Knowledge, (w:) P. Winston (red.): The Psychology of Computer Vision. New York, 211-277.

Newell, A./ H. Simon (1972), Human Problem Solving. Englewood Cliffs.

Rosch, E. (1975), Cognitive representations of semantic categories, (w:) ,Journal of Experimental Psychology: General" 104, 192-233.

Schank, R./ R. Abelson (1977), Scripts, Plans, Goals and Understanding. An Inquiry into Human Knowledge system. Hillsdale.

Talmy, L. (1988), Force Dynamics in Language and Cognition, (w:) „Cognitive Science" 12, 49-100.

Taylor, J. (2003), Linguistic Categorization. Prototypes in Linguistic Theory. Oxford.

Varela, F./ E. Thompson/ E. Rosch (1991), The embodied mind: Cognitive science and human experience. Cambridge.

Ziem, A. (2008), Frames und sprachliches Wissen. Kognitive Aspekte der semantischen Kompetenz. Berlin. 